\title{
Cobalt-Catalyzed Enantio- and Diastereoselective Hydroacylation Reaction
}<smiles></smiles>

$(0.3 \mathrm{mmol})$<smiles>[R]C1C(=O)c2cc[Y1]([H])cc2C1[R7]</smiles>

66-99\% yield $11-98 \%$ ee dr from $3.4: 1$ to $>20: 1$

Selected examples:<smiles>CCCCCC1C(=O)c2cc(OC)ccc2C1CCCC</smiles>

$92 \%$ yield $91 \%$ ee $d r>20: 1$<smiles>C[C@H]1c2ccccc2C(=O)[C@H]1c1cccc(F)c1</smiles>
$96 \%$ yield
$97 \%$ ee $97 \%$ ee
$d r=14: 1$<smiles>O=C1c2c(ccc3ccccc23)[C@@H](c2ccccc2)[C@H]1c1ccccc1</smiles>

Ph<smiles>CC1C(=O)c2ccccc2[C@H]1c1ccc(Cl)cc1</smiles>

$66 \%$ yield $91 \%$ ee $\mathrm{dr}=7: 1$<smiles>C[C@H]1c2ccccc2C(=O)C1c1ccccc1</smiles>
$81 \%$ yield $96 \%$ ee
$d r>20: 1$<smiles>C[C@H]1C(=O)c2ccccc2[C@H]1c1ccc(C(F)(F)F)cc1</smiles>

\section{$78 \%$ yield $63 \%$ ee} $\mathrm{dr}=6: 1$<smiles>COc1ccc([C@H]2C(=O)c3ccccc3[C@@H]2C)cc1</smiles>

$86 \%$ yield $93 \%$ ee $d r>20: 1$<smiles>C[C@H]1C(=O)c2ccccc2[C@H]1c1cccs1</smiles>

$70 \%$ yield $11 \%$ ee $\mathrm{dr}=3.5: 1$

Deuterium-labelling experiment:<smiles>[2H]C(=O)c1ccccc1/C(C)=C/c1ccccc1</smiles>

$\mathrm{CoBr}_{2}(5 \mathrm{~mol} \%)$ $(R, R)$-BDPP (5 mol\%) $\mathrm{Mn}(50 \mathrm{~mol} \%)$ DMF, $80^{\circ} \mathrm{C}, 12 \mathrm{~h}$

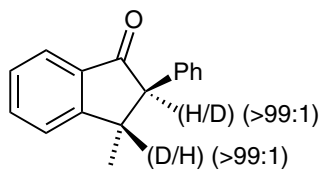

Significance: A cobalt-catalyzed hydroacylation reaction is described. By using a simple chiral bisphosphine ligand, the authors were able to furnish various enantioenriched indanones in moderate to excellent yields, enantioselectivity, and diastereoselectivity.
Comment: Hydroacylation reactions are typically carried out with expensive rhodium catalysts. The application of less expensive cobalt catalyst enabled the authors to hydroacylate trisubstituted olefins under mild conditions. The mechanism is presumed to be analogous to that of the rhodiumcatalyzed hydroacylation reaction.

\section{Key words}

cobalt catalysis

hydroacylation

trisubstituted alkenes

indanones

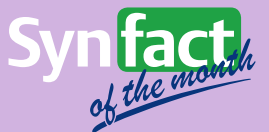

SYNFACTS Contributors: Mark Lautens, Alvin Jang

Dol: 10.1055/s-0036-1590113; Reg-No.: L01517SF 